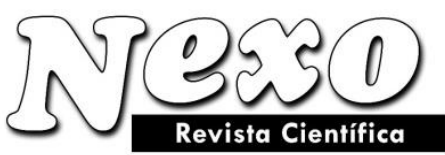

Vol. 34, No. 04, pp. 1355-1369/Septiembre 2021
ISSN-E 1995-9516

Universidad Nacional de Ingeniería COPYRIGHT @ (UNI). TODOS LOS DERECHOS RESERVADOS

http://revistas.uni.edu.ni/index.php/Nexo https://doi.org/10.5377/nexo.v34i04.12670

\title{
Conceptual models of tax systems of asian states at different stages of economic development on the example of Japan and China
}

\section{Modelos conceptuales de sistemas tributarios de estados asiáticos en diferentes etapas de desarrollo económico en el ejemplo de Japón y China}

\author{
Vladimir Alexandrovich Slepov ${ }^{1, *}$, Mikhail Evgenievich Kosov ${ }^{1,2}$, Mikael Edvardovich \\ Khoranyan $^{2}$, Sergey Aleksandrovich Balandin ${ }^{1}$, Sergey Yuryevich Popkov ${ }^{3,4}$ \\ ${ }^{1}$ Plekhanov Russian University of Economics. Moscow, Russian Federation. \\ ${ }^{2}$ Financial University under the Government of the Russian Federation. Moscow, Russian Federation. \\ ${ }^{3}$ Moscow City Government University of Management. Moscow, Russian Federation. \\ ${ }^{4}$ All-Russian Research Institute of Labor. Moscow, Russian Federation. \\ *Corresponding author E-mail: slepov.v.a@ mail.ru
}

(recibido/received: 02-mayo-2021; aceptado/accepted: 25-julio-2021)

\begin{abstract}
The purpose of the study is to determine the role of the stage of economic development on the conceptual model of taxation in Western countries by analyzing the tax systems of Japan and China. The article provides a fundamental analysis of the tax systems of Japan and China, which includes the study of the internal macroeconomic conditions of the tax policy, the analysis of the fundamental factors of the implementation of the tax model used. Parallels have been drawn between the industrial (the predominant share of industry in the structure of the economy) China and post-industrial Japan (the predominant share of the service sector and the high rate of introduction of innovative technologies into the economy). The features characteristic of the industrial and post-industrial tax systems of the countries of the Asian region have been formulated based on the conducted analysis. The conclusion of the study was a vector model that characterizes the main elements of the tax policy.
\end{abstract}

Keywords: Tax system; Tax incentives; Japan; China; Asia.

\section{RESUMEN}

El propósito del estudio es determinar el papel de la etapa de desarrollo económico en el modelo conceptual de tributación en los países occidentales mediante el análisis de los sistemas tributarios de Japón y China. El artículo proporciona un análisis fundamental de los sistemas tributarios de Japón y China, que incluye el estudio de las condiciones macroeconómicas internas de la política tributaria, el análisis de los factores fundamentales de la implementación del modelo tributario utilizado. Se han establecido paralelos entre la China industrial (la participación predominante de la industria en la estructura de la economía) y el Japón posindustrial (la participación predominante del sector de servicios y la alta tasa de introducción de tecnologías innovadoras en la economía). Los rasgos característicos de los sistemas tributarios industriales y postindustriales de los países de la región asiática se han formulado con 
base en el análisis realizado. La conclusión del estudio fue un modelo vectorial que caracteriza los principales elementos de la política tributaria.

Palabras claves: Sistema de impuestos; Incentivos fiscales; Japón; China; Asia.

\section{INTRODUCTION}

As Schumpeter (1954, p. 117) noted, "... nothing more clearly reflects the nature of society and civilization than the fiscal policy pursued by the political sector of this society."

In this regard, to understand the ways of forming alternative concepts of tax regulation, it is necessary to understand the tax system not only as a certain set of taxes and other mandatory payments but also as a special combination of tax institutions (rules and tools) that guide the behavior of economic entities that operate in a specific geographical and cultural environment (Vishnevskii, Goncharenko and Gurnak, 2016). This approach makes it possible to better justify the choice of the main directions of reforms in a particular sector of the economy, especially for industries that are traditionally characterized by a special economic environment, due, among other things, to a specific combination of inclusive and extractive institutions that guide economic development (Sigarev, Kosov, Buzdalina, Alandarov and Rykova, 2018).

As J. Diamond (2010) noted, "... today there is a growing understanding that the "institutional" approach to the problem is insufficient - not erroneous, namely insufficient ... One cannot simply share the experience of effective institutions with poor countries like Paraguay and Mali and expect them to apply the knowledge gained and, in terms of GNP per capita, catch up with the United States and Switzerland.... Effective institutions are not a random parameter that could be equally likely to appear in any society on the planet, be it Denmark or Somalia. From my point of view, effective institutions have always emerged as a result of a long chain of historical accomplishments - the ascent from initial factors of a geographic nature to direct factors derived from them, among which there are institutional ones" (p. 324). In this regard, the issues related to the study of the experience of foreign countries are of crucial importance for the formation of a fundamental basis for tax reforms in other countries.

\section{METHODOLOGY}

To study the foundations of the formation of the tax systems of Japan and China, which are characterized by a high degree of traditionalism and expressions of respect for what existed before, the period after the twentieth century is of greatest interest, in particular for the study of Japan, which suffered the greatest losses in the Asian regions during the Second World War.

It was at this time that the main concepts and theoretical trends were developed, which formed the basis for laying the groundwork for the formation of China and Japan as one of the key economies of the world.

To conduct the study, we analyzed the structure of the economies of Japan and China, analyzed their tax system and key operating taxes. Also, a general macroeconomic analysis was carried out, aimed at forming an understanding of the key features of the economy of the countries under consideration.

\section{RESULTS AND DISCUSSION}

The model of the state's tax system depends on many factors. First of all, it depends on the level of economic development, the goals of tax policy, and the quality of tax administration. In this study, we will characterize the tax systems of such countries of the Far East as Japan and China, comparing their features with the stages of economic development. Both countries make a significant contribution to global GDP. 
According to the IMF, as of December 1, 2019, China's share in global GDP exceeds 16\% (China is second in this indicator only to the United States), and Japan - almost reaches 6\% (third place in the world) (Figure 1).

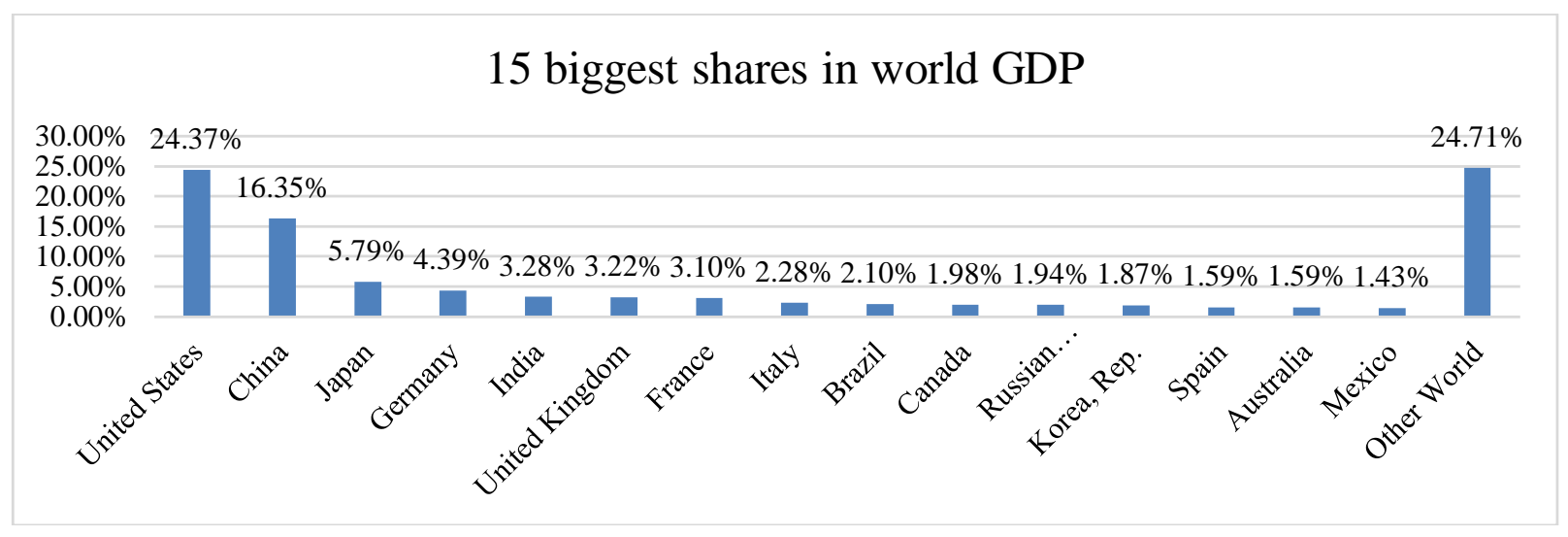

Figure 1. Share of the world's largest economies in global GDP Compiled from World Bank Database (World Bank, n.d.)

At the same time, the two states under consideration are at different stages of economic development, which cannot but affect the peculiarities of the organization of their tax systems (Kosov, Akhmadeev, Smirnov, Solyannikova and Rycova, 2018; Kosov, Akhmadeev, Osipov, Kharakoz and Smotritskaya, 2016).

When conducting the study, we will rely on the division of economies by stages of development into:

- $\quad$ pre-industrial economy;

- $\quad$ mixed economy;

- industrial economy;

- $\quad$ post-industrial economy;

- the knowledge economy (Kosov, Sigarev, Sharov, Makashina and Smirnov, 2020).

Based on the provisions set out in the works of Schumpeter (1954), Inozemtsev, (2011), we will characterize the stages of development of the economies of China and Japan and determine the features of the tax systems of these states as typical representatives of their stage of economic development (but taking into account the specifics of the region).

\section{The people's Republic of China}

The economy of the People's Republic of China should be classified as industrial. Moreover, the PRC can be characterized as a new (or rather, the newest) industrial country. China is a NIS of the Asian model, which implies the development of the national economy with a primary focus on the external market. The following factors allow drawing this conclusion:

1. High rates of economic growth (Figure 2). 
The graph data confirms that the growth rate of the Chinese economy exceeds the growth rate of the main developed countries.

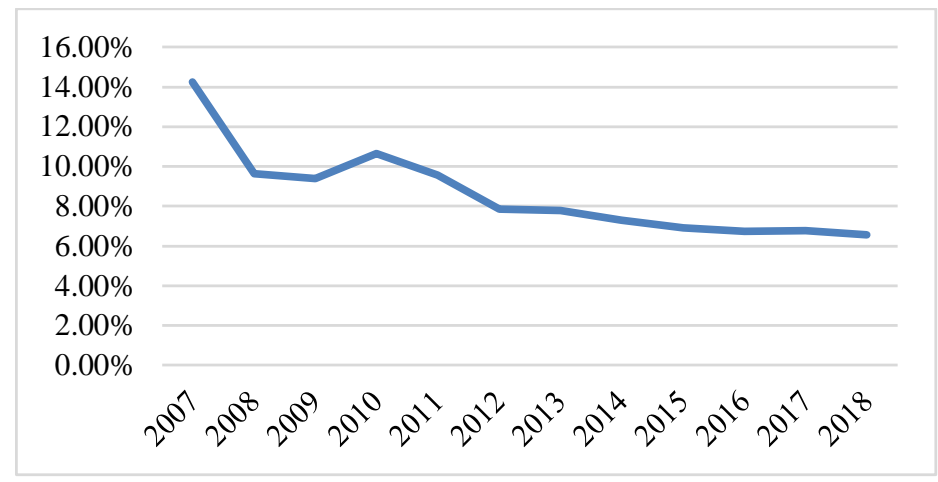

Figure 2. China's GDP growth rate, 2007-2018

Compiled from World Bank Database (World Bank, n.d.)

2. High share of industry in the structure of the national economy. As of 2015, the structure of the Chinese economy is shown in Figure 3.

According to some industry data, based on the results of 2019 , the industry will create $47 \%$ of China's GDP (forecast).

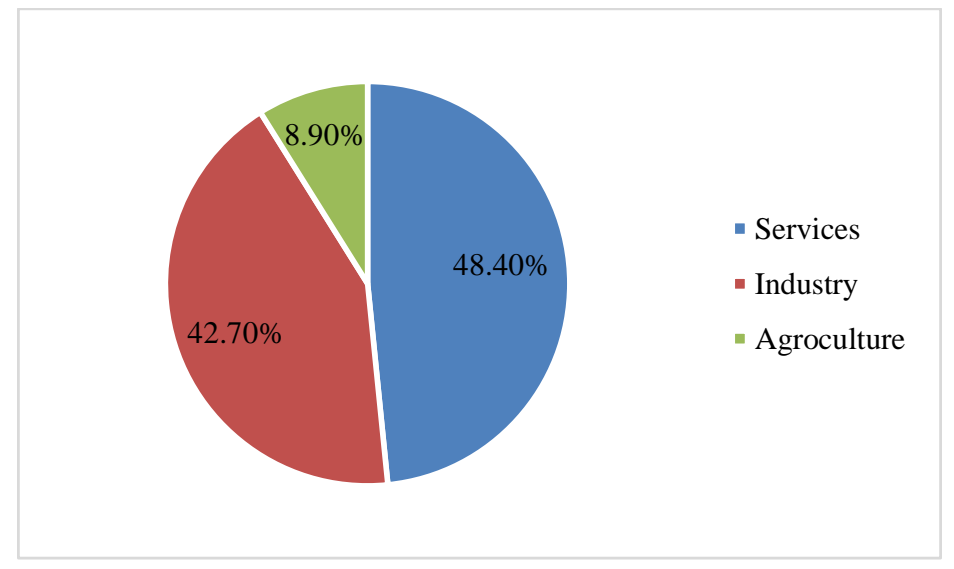

Figure 3. Structure of the Chinese economy

3. Export-oriented economy. According to the Ministry of Commerce of China (MOFCOM), at the end of 2015, China's foreign trade turnover amounted to 3.96 trillion US dollars (exports -2.28 trillion US dollars, imports - 1.68 trillion US dollars). Taking into account the size of China's GDP for the same period, it can be noted that the volume of exports amounted to $21.9 \%$ of GDP in 2015.

4. Active integration. The PRC is (as of 2016) a party to 15 free trade area agreements, including ASEAN, Singapore, Pakistan, Chile, Peru, New Zealand, Costa Rica, Iceland, Switzerland, the Republic of Korea, and Australia, as well as a party to two agreements on close trade and economic relations (PRCHong Kong), (China-Macau) and one framework agreement on economic cooperation between the mainland of the PRC and Taiwan. A bilateral agreement has been signed with the United States (which is currently under threat due to US sanctions). A similar bilateral investment agreement between the PRC and the EU countries is under discussion and is scheduled to be signed in 2020. China has been a member 
of the WTO since 2001. Since joining the WTO, China has reduced tariffs and duties and lifted restrictions on enterprises to conduct independent foreign trade operations. During the years of WTO membership, the overall level of China's customs tariffs on imported goods has been decreased from $15.3 \%$ to $9.8 \%$.

5. Use of high technologies. The large-scale generation of innovative technologies is a distinctive feature of the post-industrial economy. China is not a producer of innovation. It is an active consumer of them. That is, China produces a large number of high-tech goods, most of which it exports based on technologies created in developed economic countries (with a post-industrial economy). China is engaged in the "monetization" of innovations generated by post-industrial economies (Gonzalez and Hosoda, 2016).

6. Multinational corporations - both the formation of their own and the attractiveness for foreign ones. According to the Financial Times Global 500 ranking, in 2015, 37 Chinese organizations were included in the list of large and influential companies around the world. The largest TNCs of the PRC are presented in Table 1.

Table 1. China's Largest TNCs

\begin{tabular}{cccc}
\hline $\begin{array}{c}\text { Place in the } \\
\text { Financial Times } \\
\text { Global 500 ranking }\end{array}$ & Company Name & Industry & $\begin{array}{c}\text { Assets } \\
\text { (US Dollars Billion) }\end{array}$ \\
\hline 2 & Sinopec Group & Oil Refining & 359.2 \\
4 & Ohina National Petroleum & Oil Refining & 634.8 \\
7 & State Grid & Energetics & 466.3 \\
37 & China State Construction & Construction & 148.9 \\
55 & Engineering & Telecommunications & 246.7 \\
60 & China Mobile Communications & 66.9 \\
71 & SAIC Motor & Mechanical engineering & 110.5 \\
72 & China Railway Engineering & Construction & 180.4 \\
77 & China National Offshore Oil & Mining & 20.1 \\
79 & Noble Group & industry & 101.6 \\
94 & China Railway Construction & Construction & 442.6 \\
\hline
\end{tabular}

7. Another sign of belonging to the NIS is that the new (newest) industrial countries have made the production of household appliances and computers, clothing, and footwear their trademarks. This applies to China in the most superlative degree. It is a manufacturing country for almost all well-known brands in the world, as well as for non-branded products.

Thus, based on all of the above, we consider that the PRC belongs to the new industrial countries to be proven. At the same time, the conducted research suggests that China is preparing to make a leap forward and move from the NIS category to the post-industrial stage of development.

Based on the analysis of the tax system of the People's Republic of China, we will highlight the main features characteristic of the tax systems of the new industrial countries. The main goal of the tax policy of countries at this stage of economic development is to create a favorable economic and investment climate. The tax system is focused on the priority expansion of capital, attracting foreign investment. In the PRC, this goal is achieved using a set of measures. In particular, indirect taxes predominate in the structure of tax revenues (Figure 3). 
Also, the statistics presented in Figure 4 include the business tax, which is collected from entrepreneurs from the proceeds from the performance of works, the provision of services, as well as from the transfer of property rights. The proceeds from the sale of goods are subject to VAT. Such a structure of the tax system allows transferring the burden of taxation from organizations to the population.

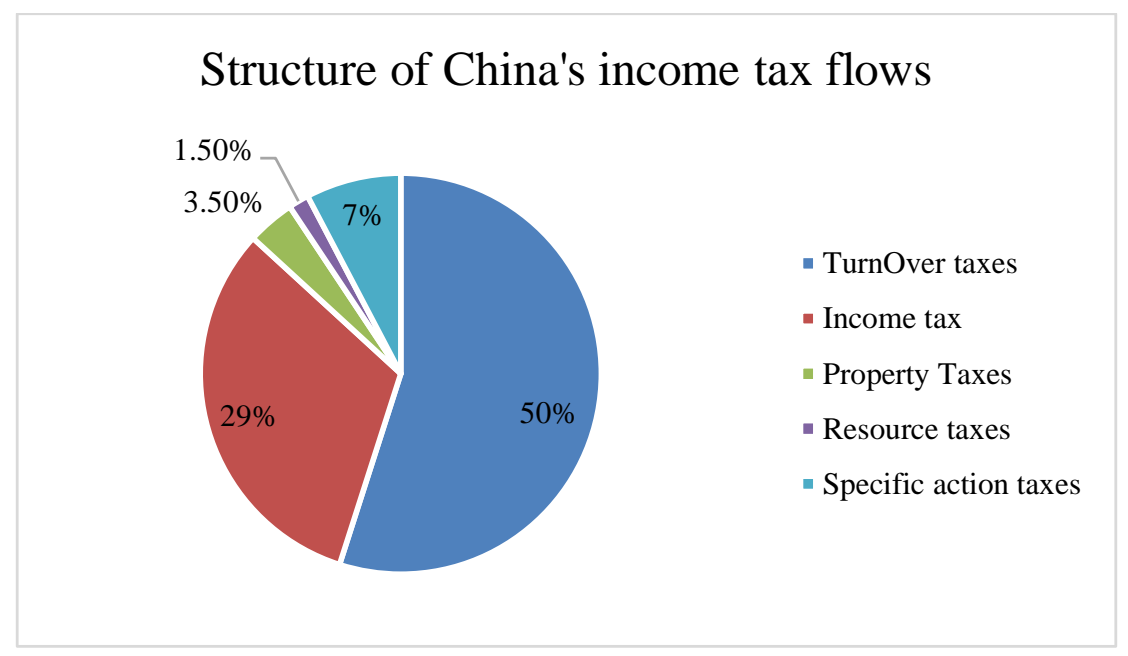

Figure 4. Structure of tax revenues in China

The company income tax (corporate tax) rate as of 2019 is $25 \%$. This was the result of corporate tax reform. The desire to create favorable conditions for attracting foreign capital led to the fact that the tax system in the PRC offered significantly more favorable conditions for enterprises with direct foreign investment. In particular, to attract foreign direct investment and promote economic growth, the Chinese government has granted various political and tax preferences to foreign investors since the 1990s. Businesses with foreign investment had lower tax rates and broader deductions from the corporate income tax base than Chinese firms before 2011. For example, by the end of 2007, enterprises with foreign investments had significantly lower income tax (corporate tax) rates $-15 \%$, compared to the reaching 33\% for Chinese firms (Yuchen and Chengrui, 2019). Until 2009, only foreign-invested companies were allowed to deduct domestically acquired capital equipment investments from the value-added tax base. Until 2006, only companies with foreign investments had the right to include employee salaries in the corporate tax base at a rate of $100 \%$. Domestic firms could only include wage costs in the tax base within the quota, which was 800 yuan per month per employee.

Such a policy, on the one hand, reduced the cost of Chinese goods, kept the cost of labor at a low level, and on the other - increased the tax burden on the manufacturer and reduced the financial capacity of firms to invest. The Chinese central government has launched a series of reforms to gradually reduce the differences in tax policy between enterprises with foreign investment and domestic firms to create an integrated tax system for all firms. The central government officially announced the transformation of the corporate tax base (corporate income tax) for Chinese firms in July 2006.

Income taxation of individuals is represented by a progressive scale of taxation (from 3 to $45 \%$ ). The extent of the scale brings China closer to the tax systems of developed post-industrial countries. It should be taken into account that the majority of the population pays tax at low rates (10-15\%). Income tax in China (compared to post-industrial countries) does not involve a significant number of benefits and deductions. Thus, the desire to invest in human capital, which is typical for the tax systems of postindustrial economies, is not yet observed in the PRC. Awareness of the high importance of the quality of 
human capital, the level of education, etc. in the PRC has already been achieved. Only the practical implementation of this trend has not yet fully affected the country's tax system.

As part of the reduction of the tax burden on business and its transfer to the population, social insurance is financed equally at the expense of the employer and the employee. Despite this, the rate of social insurance contributions is extremely high for the industrial economy $-48 \%$ (of which $11 \%$ is deducted from the employee's salary). The range of payers and the direction of the use of funds is not clear without an in-depth analysis of the social insurance system, since the pension system in China is provided for a very limited number of employees (mainly civil servants).

The tax system of the People's Republic of China is not characterized by excessive centralization. Tax revenues are credited in approximately equal amounts to the state and local budgets. The level of tax revenues in the total amount of budget revenues is quite high - more than 85\% (Yartseva, 2015).

The tax burden of industrial countries is usually characterized by relatively low values (which contributes to rapid economic growth). The level of the tax burden in China is at a loss below the global average. For example, according to the IMF, in 2009 the level of the tax burden (the median value) for the group of countries that includes China was $\mathbf{1 6 . 5 \%}$. While in China itself, the tax burden for the same period was $14.9 \%$.

Another characteristic feature of the Chinese tax system is its export orientation. Export promotion is carried out, among other things, through VAT refund on export (recall that the sale of goods in the PRC is subject to VAT, and the sale of works and services is subject to business tax). However, VAT refunds are seen not only as an incentive for exports. Chinese researchers consider it as an alternative financial instrument for financing investment activities. It is the optimal solution for those enterprises that seek to invest in Research and Advanced Development. Because of the high risk and "immateriality" of investments, banks refuse to lend them. In this case, the source of financing for investment in innovation is the VAT refund on exports (Dongyang, 2019).

The results of the analysis suggest that the Chinese economy is approaching the limit of the industrial stage of development and is beginning to prepare for the transition to the post-industrial stage (which is expected in the long term, but the prerequisites for this are already emerging). In particular, the growth opportunities of the NIS were almost exhausted - the economic growth rate decreased from 9-10\% of GDP to $6 \%$. These opportunities consisted in the use of low labor (which allowed both reducing the cost of goods of domestic production, and facilitating the transfer of industrial production from post-industrial countries to their territory); copying (and sometimes direct plagiarism) of technologies, including innovative ones developed in post-industrial countries; active attraction of direct foreign capital, providing it with more favorable tax conditions compared to domestic business. Currently, the tax policy of the People's Republic of China is to equalize the conditions of activity of foreign and domestic companies, trying to stimulate their Research and Advanced Development. In particular, until 2006, the corporate tax (corporate income tax) deduction rules for firms' Research and Advanced Development spending in China discriminated against private domestic firms. Only two groups of firms, namely firms with foreign direct investment participation and state/collective enterprises, had Research and Advanced Development tax benefits and could deduct Research and Advanced Development expenses in the amount of $150 \%$ of the pre-tax expenses incurred. Other domestic firms (mostly private ones) were only allowed to deduct $150 \%$ of their Research and Advanced Development expenses if they met certain requirements and received certificates from local tax authorities (this option only appeared in 2004).

Studies conducted by Chinese scholars have shown that in the Chinese economy, manipulating corporate tax rates has less effect in stimulating innovation activity than making changes to the procedure for calculating the tax base for corporate income tax (although the latter method has a time lag and begins to 
produce results in at least 2-3 years) (Kosov, Solyannikova, Sigarev, Karpenko and Popkov, 2019; Yuchen and Chengrui, 2019).

Another indicator of the "maturity" of the industrial stage of the development of the Chinese economy and its preparation for the transition to the next stage is the development of environmental taxation. Economic growth in industrial economies is based on large-scale growth in industrial production. A side effect of such a policy is the significant damage caused to the environment due to the irrational (inefficient) use of resources and environmental pollution. The inclusion of a carbon tax in the Chinese tax system is on the agenda in China. At the moment, the impact of the introduction of the tax on the regions and sectors of the economy is being investigated, and the optimal mechanism for calculating the amount of the tax and the direction of its use is being selected (Kun, Mei-Mei, Kuishuang and Qiao-Mei, 2019; Qingwei, Hong, Weiguang and Jingxin, 2019). The tax reform of the coal mining industry (as the main supplier of energy resources in the country) has already been successfully carried out. There was a transition from a fixed to an ad valorem tax rate, which positively influenced both the price of coal and its supply, and led to a decrease in the tax burden on coal mining enterprises (Huihui, Zhan and Jianliang, 2017; Kasahara, Shimotsu and Suzuki, 2014).

Thus, the peculiarities of the tax system of the countries of the Far East, the economies of which can be attributed to the newest industrial ones, include (for example, the PRC):

1. The priority direction of the development of the country's tax system is the full support of entrepreneurial activity, the expansion of capital, and investment. The main burden of the tax burden has been shifted from direct taxation to indirect taxation.

2. The share of tax revenues in the structure of state revenues is high. The absence of excessive centralization in the receipt of tax payments. The overall level of the tax burden (at the macro level) is low.

3. The tax system is focused on providing foreign investors with numerous benefits and preferences.

4. Tax legislation encourages the export of finished products.

5. The tax systems of countries that have almost completely exhausted the possibilities of the industrial stage of economic development are characterized by the following features:

1) tax incentives for Research and Advanced Development and innovation (instead of technology imports);

2) development of environmental taxation that promotes more efficient use of resources and minimizes environmental damage caused during the period of industrial development).

\section{Japan}

Japan's economy is at a post-industrial stage of development. This is evidenced, in particular, by the high cost of GDP per capita - 48919.6 USD, while the GDP growth rate is quite low (Figure 5), which is typical for post-industrial countries. 


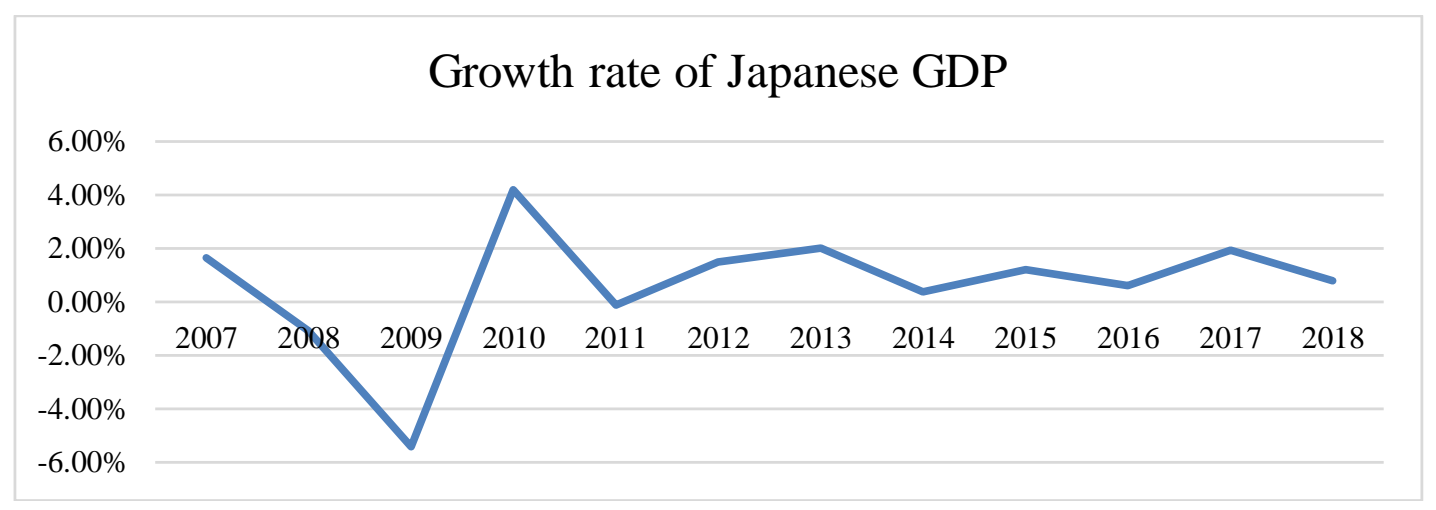

Figure 5. Japan's GDP growth rate

The structure of the Japanese economy also corresponds to the post-industrial stage. As of 2015, the share of services in the Japanese economy was $72.2 \%$ (Figure 6).

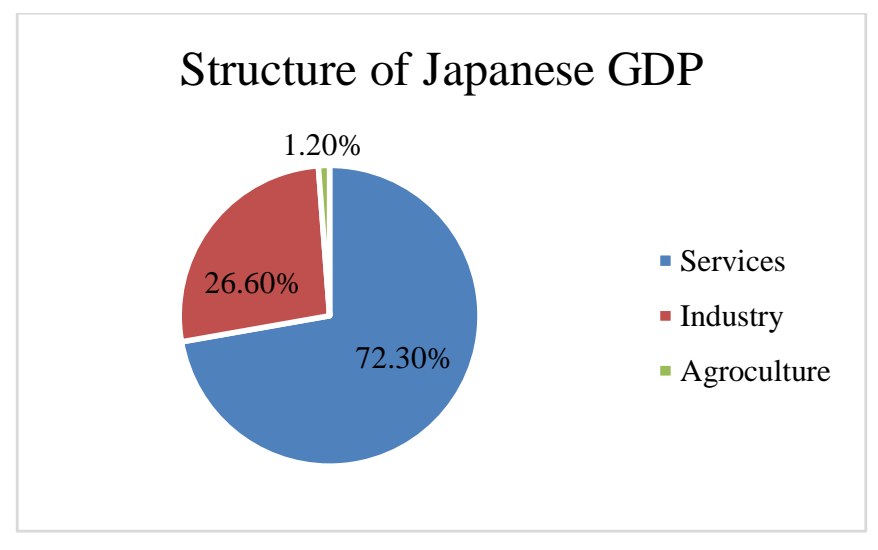

Figure 6. Japan's GDP structure

Japan is an active participant in international economic organizations such as the OECD, the WTO, the Trans-Pacific Partnership, the Asia-Pacific Economic Cooperation; the Pacific Economic Council; the Pacific Economic Cooperation Council; the East Asia Summit; and the ASEAN Regional Forum. Japan has concluded 13 free trade and economic partnership agreements: with ASEAN, Brunei, Chile, India, Indonesia, Malaysia, Mexico, Peru, Philippines, Singapore, Thailand, Switzerland, Vietnam (Slepov, Kosov, Burlachkov, Grishina and Sakharov, 2019).

Japan accounts for a significant number of innovations and high-tech developments. Japan is a member of the World Intellectual Property Organization (WIPO). In 2014, Japan ranked third in WIPO's ranking of patent applications from residents (266 thousand applications; for comparison: China -800 thousand applications). As of 2014, the country's Research and Advanced Development expenditure was 3.6\% of GDP. Japan is ranked 22nd in the World Bank's Knowledge Economy Index (2014), and 19th in the Global Innovation Index (2015) (Bykanova et al., 2017).

Thus, it can be stated that the Japanese economy meets all the criteria inherent in post-industrial economies, such as:

- $\quad$ high labor productivity; 
- a significant amount of GDP (including per capita), together with low economic growth (especially in the industry);

- the low share of industrial production and predominance of the service sector;

- $\quad$ awareness of the high importance of the quality of human capital;

- a significant sector of the innovative economy with high technologies and venture capital business.

Using the example of Japan, we will characterize the typical features of the tax systems of post-industrial countries.

The Japanese tax system is characterized by a high degree of centralization of tax revenues. When building a tax system, priority is given to state taxes over prefectural and local taxes. About $2 / 3$ of the tax revenue comes from them. In the future, the received tax payments are redistributed between the budgets of the Japanese budget system. Meanwhile, it should be noted that the legislator has attempted to reduce the volume of inter-budget transfers by the delegation of power to collect tax payments to the prefectural and local levels in the last decade. Moreover, the share of tax revenues in the Japanese budget system is relatively small. In the state budget, non-tax revenues are approximately $15-16 \%$, in local budgets up to $25 \%$.

Priority is given to direct taxes, which form the basis of the budget of any level of the Japanese budget system. This characterizes the Japanese tax administration system as efficient and highly developed. However, lawmakers have sought to shift the focus from direct taxation to indirect taxation in recent decades.

The Japanese tax system is aimed at implementing the regulatory function of taxation. Despite one of the highest corporate tax rates in the OECD $(30.86 \%)$, it contains a significant number of benefits and preferences aimed primarily at creating a favorable investment climate and prioritizing the development of certain regions (primarily peripheral ones), as well as the structural restructuring of the national economy. Moreover, benefits and preferences are provided not only to domestic investors but also to foreign ones. The system of tax benefits currently in force is based on various types of laws on regional development and consists mainly of measures to reduce or even completely exempt from local taxes.

As it was shown above, Japan occupies one of the leading places in the world in terms of the number of high-tech developments and innovations. Research and Advanced Development accounts for about 3.6\% of GDP. This situation became possible only with the state stimulation of the innovative activity of companies. A prominent place in the framework of this program is given to tax incentives. The Japanese tax legislation sees the solution to the problem of financing scientific research with limited own financial resources and the impossibility of credit financing in the provision of a tax credit for Research and Advanced Development. The system of supplementary tax credits operated in Japan until 2002. Under the old system, only firms, Research and Advanced Development expenditures of which, in the current fiscal year exceeded the average of the three largest annual Research and Advanced Development expenditures over the past 5 years could receive a tax credit for Research and Advanced Development. In the general system of tax credits that emerged after the 2003 reform, the tax credit is applied to total Research and Advanced Development expenditures regardless of past expenditures for these purposes. Research conducted by Hasegawa (2017) shows that the corporate tax reform in 2003, which resulted in a change in the terms of the Research and Advanced Development tax credit, led to an increase in total Research and Advanced Development expenditures by $3.0-3.4 \%$. Moreover, the study allows the authors to conclude that limiting the size of the tax credit to twenty percent of the tax base did not allow for an increase in Research and Advanced Development expenditures by 3.1 - 3.9\%. 
Japan, as a country at the post-industrial stage of development, is characterized by a high degree of involvement in transnational financial and industrial activities and is a country of residence for many multinational corporations. Before 2009, the Japanese tax system provided for the taxation of income received in other tax jurisdictions upon their repatriation. This led to the fact that by the end of the 2000s, a significant part of the income received abroad was not repatriated (due to taxation at a rate of about 40\%). To remedy the situation in April 2009, the use of the tax credit method was changed to the use of the exemption method to eliminate international double taxation. In particular, dividends paid by Japanese subsidiaries abroad to their parent companies were exempt from taxation. The response of Japanese subsidiaries to the dividend exemption was mixed. In particular, foreign subsidiaries with large amounts of retained earnings tended to be more responsive to the reform and significantly increased their dividend payments to their parent firms in response to the introduction of the dividend exemption system. Dividend payments by these branches have also become more sensitive to the withholding tax rates on dividends levied by the source countries. Japanese multinationals could no longer claim to use the tax credit method for withholding tax on repatriated dividends under the new exemption system.

There were changes in corporate taxation in 2018. To simultaneously support enterprises and encourage them to increase wages and reorient reserves to capital investments, special tax measures are being introduced in the form of providing a tax deduction of up to $20 \%$ and setting the actual corporate tax rate at $25 \%$ for those enterprises that in the previous financial year increased wages by $3 \%$ and made investments at a level of more than $90 \%$ of the depreciation cost of their main equipment for the corresponding period. Small and medium-sized enterprises are also subject to tax relief measures that provide for the actual level of the corporate tax rate at a similar level if wages increased by more than $1.5 \%$ in the previous fiscal year (Nakata, 2001).

Initially, the concept of reforming the taxation of legal entities is formulated as "to reduce the tax rate while expanding the tax base", in connection with which there is a certain rollback. Given the current state of the Japanese economy, the task of redirecting domestic savings to higher wages and capital investment is extremely important, and the relaxation of the tax regime is a special measure with a limited three-year validity period.

In our opinion, one of the features of the tax system of the post-industrial state is a developed system of environmental taxation. The inclusion of an environmental tax in the Japanese tax system, either in the form of a carbon tax or in the form of a tax on energy consumption, which should lead to approximately the same consequences for the environment, but is more preferable for Japan's energy security, is currently being discussed. Also, Japan has a tax on aviation fuel. It is indirect and is included in the cost of aviation fuel used in domestic flights. It was introduced into the tax system to create a financial base for the expansion and maintenance of regional airports and airfields and was never recognized as environmental. However, the use of this tax leads to a reduction in the use of jet fuel and a reduction in carbon dioxide emissions into the atmosphere.

The Japanese tax system is characterized by a high share of income tax in the structure of tax revenues. There has been a downward trend since the 90s of the twentieth century (in 1990 it accounted for $41.6 \%$ of tax revenues). During the same period, the maximum income tax rates were reduced from $70 \%$ to $50 \%$ (but in addition to the state income tax, $2-4 \%$ is paid to the prefectural budget and 3-12\% to the municipal budget). There was also a reduction in the number of steps in the calculation of income tax from 15 to 5 (Gonzalez and Hosoda, 2016). Thus, income taxation is characterized by a progressive scale of taxation with a large differentiation. The tax legislation provides for a significant number of benefits and preferences, including a non-taxable minimum for each taxpayer and dependents (in total, the non-taxable minimum for a family exceeds the similar deduction in most European countries and the United States). In addition to targeted, personal exemptions, which are widely applied to taxable income in general, there are 
several narrowly specific benefits for the taxation of income received from various sources. The Japanese income tax system includes significant elements of family taxation, which are based on the assumption that the second spouse is either unemployed or part-time and, as a result, has an income below the established value (Bessho and Hayashi, 2014). We do not consider this element as a characteristic feature of the post-industrial economy. Most likely, this is evidence of the regional peculiarities of the tax system. This element of income taxation remained as a relic of the traditional patriarchal way of life in Japanese society when a married woman left work after marriage.

Japan is one of the few countries in which social taxes exceed income tax receipts in the total collection. The social insurance contribution rate is $29.65 \%$, of which $14.45 \%$ is paid by the insured themselves.

The effectiveness of Japan's tax system and methods of tax regulation is indirectly confirmed by a very narrow sector of the shadow economy. According to the studies by F. Schneider and D. Enste (2004) at the end of the twentieth century, the share of the shadow economy in Japan was 8.5\%, which is one of the lowest rates in the world (even for developed post-industrial countries).

Thus, on the example of Japan, it is possible to distinguish the features of tax systems inherent in the postindustrial economies of the Far East:

1. The complexity, ramifications, and volume of tax legislation, the multiplicity of types of tax payments (Osipov, 2017).

2. A high degree of centralization of tax revenues in the state budget, a relatively low share of tax revenues in budget revenues.

3. The predominance of direct taxation over indirect taxation.

4. A high share of tax revenues from income taxation and social insurance contributions.

5. The high level of corporate income taxation characteristic of developed economies, and the lack of preferences for non-residents. A pronounced focus of the tax system on the implementation of the regulatory function (providing significant benefits and preferences to taxpayers, both domestic and foreign, who invest following the state program for the development of industries and regions).

6. The system of tax incentives for Research and Advanced Development and innovation.

7. No taxation of repatriated income.

8. The presence of more or less developed environmental taxation.

A low share of the shadow economy (which characterizes the effectiveness of the tax system).

\section{CONCLUSION}

The analysis showed that, depending on the stage of economic development of the country, the tax system reflects the goals, objectives, and features inherent in this stage. This leads to the emergence of conceptual features of tax systems that are characteristic of states that are at similar stages of economic development.

Summing up the results of the theoretical analysis, as well as the analysis of the practice of forming various models of tax regulation in Japan and China, the relationship of taxes with technologies, regulatory rules, and institutions can be represented in the form of three vectors. For each of these vectors, 
depending on the expected state of affairs (T1, T2, I1, I2, R1, R2, etc.), appropriate alternatives to the tax policy of different content can be adopted, as well as a lesser or greater degree of intensity (vector) (Figure 7).

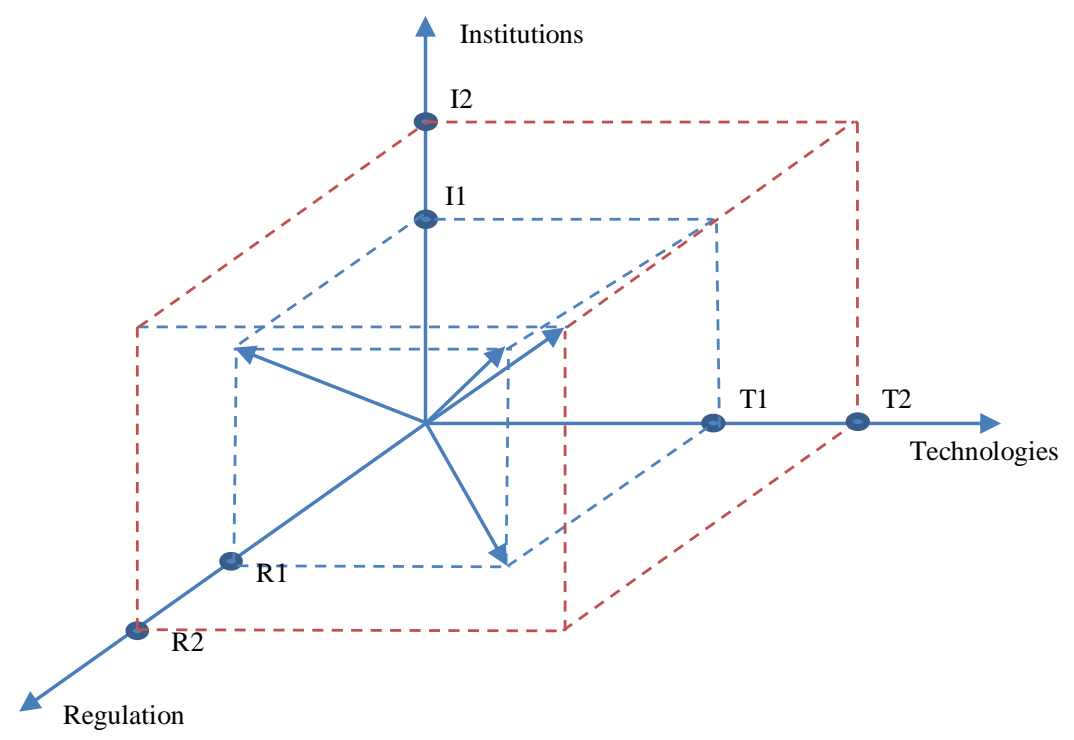

Figure 7. Graphic illustration of alternatives to tax regulation as a factor in ensuring the new industrial revolution

As for technology, if the country, for example, is rapidly growing the density of industrial robots, then the issue of a tax on robots can also be included in the agenda. The accelerated development of digital technologies, which is relatively successful, may require changes in terms of reducing the rate and relative value of the corporate income tax, which in the conditions of a digital globalized economy is easy to hide by tax planning methods, and for the reason that this tax in principle does not contribute to economic growth.

Concerning tax rules that take into account the specifics of tax methods of regulating the economy, we can consider introducing regulatory requirements in terms of prohibiting changes in the basic norms of tax legislation for a certain period, and/or establishing a certain limit level of tax withdrawal of income (similar to the cut-off price per barrel of oil in the budget rule) with automatic allocation of excess amounts for the development of the national economy.

Finally, concerning institutions, possible areas of reform may include simplification of the tax mechanism, which reduces the possibilities of tax planning and tax evasion by reducing discretionary rules of economic law, various types of tax benefits and preferences, and/or giving tax rules a more social orientation through objective monitoring of the personal circumstances of taxpayers, based on the transparent use of "big data", etc.

These proposals are like conceptual provisions of the general plan, since more vectors can be proposed, and there can be many points on them, and the proposed tax response measures can be very diverse. Therefore, further research will focus on a substantive analysis of the entire complex of outlined problems, starting with an in-depth analysis of the theories of state tax regulation of representatives of economic schools of the past from the point of view of the present, and ending with the study of the experience of building tax systems in different countries at various stages of their economic development. 


\section{REFERENCES}

Bessho, Sh. and Hayashi, M. (2014). Intensive margins, extensive margins, and spousal allowances in the Japanese system of personal income taxes: a discrete choice analysis. Journal of the Japanese and International Economies, 34, 162-178.

Bykanova, O. A., Akhmadeev, R. G., Kosov, M. E., Ponkratov, V. V., Osipov, V. S. and Ragulina, Y. V. (2017). Assessment of the economic potential of sovereign wealth funds. Journal of Applied Economic Sciences, 12 (1), 70-84.

Diamond, J. (2010). A history of human communities. Moscow, Russia: AST, 604 p.

Dongyang, Z. (2019). Can export tax rebate alleviate financial constraint to increase firm productivity? Evidence from China. International Review of Economics and Finance, 64, 529-540.

Gonzalez, R. and Hosoda, E. B. (2016). Environmental impact of aircraft emissions and aviation fuel tax in Japan. Journal of Air Transport Management, 57, 234-240.

Hasegawa, M. and Kiyota, K. (2017). The effect of moving to a territorial tax system on profit repatriation: evidence from Japan. Journal of Public Economics, 153, 92-110.

Huihui, L., Zhan, M. C. and Jianliang, W. (2017). The impact of resource tax reform on China's coal industry. Energy Economics, 61, 52-61.

Inozemtsev, V. (2011). Reconstructing the industrial world. Russia in Global Politics, 6 (9), 85-98.

Kasahara, H., Shimotsu, K. and Suzuki, M. (2014). Does an R\&D tax credit affect R\&D expenditure? The Japanese R\&D tax credit reform in 2003. Journal of the Japanese and International Economies, 31, $72-97$.

Kosov, M. E., Akhmadeev, R. G., Osipov, V. S., Kharakoz, Y. K. and Smotritskaya, I. I. (2016). Socioeconomic planning of the economy. Indian Journal of Science and Technology, 9 (36), 102008.

Kosov, M. E., Akhmadeev, R. G., Smirnov, D. A., Solyannikova, S. P. and Rycova, I. N. (2018). Energy industry: effectiveness from innovations. International Journal of Energy Economics and Policy, 8 (4), 8389.

Kosov, M. E., Sigarev, A. V., Sharov, V. F., Makashina, O. V. and Smirnov, V. M. (2020). Sovereign wealth funds: Russian and international experience. Space and Culture, India, 7 (4), 246-254.

Kosov, M. E., Solyannikova, S. P., Sigarev, A. V., Karpenko, V. P. and Popkov, S. Y. (2019). Public investment in Russia: peculiarities of implementation and ways to improve efficiency. Journal of Advanced Research in Law and Economics, 10 (4), 1288-1295.

Kun, Z., Mei-Mei, X., Kuishuang, F. and Qiao-Mei, L. (2019). The economic effects of the carbon tax on China's provinces. Journal of Policy Modeling, 41, 784-802.

Nakata, T. (2001). Lamont analysis of the impacts of carbon taxes on energy systems in Japan. Energy Policy, 29, 159-166. 
Osipov, V. S., Skryl, T. V., Blinova, E. A., Kosov, M. E., Zeldner, A. G. and Alexeev, A. N. (2017). Institutional analysis of public administration system. International Journal of Applied Business and Economic Research, 15 (15), 193-203.

Qingwei, S., Hong, R., Weiguang, C. and Jingxin, G. (2019). How to set the proper level of the carbon tax in the context of Chinese construction sector? A CGE analysis. Journal of Cleaner Production, 2 (4), 240248.

Schneider, F. and Enste, D. H. (2004). The shadow Economy. An international survey. Cambridge, UK: Cambridge University Press.

Schumpeter, J. A. (1954). History of economic enalysis. London, UK: George Allen and Unwin Ltd.

Sigarev, A. V., Kosov, M. E., Buzdalina, O. B., Alandarov, R. A. and Rykova, I. N. (2018). The role of chains in the Russian retail sector. European Research Studies Journal, 21 (1), 542-554.

Slepov, V. A., Kosov, M. E., Burlachkov, V. K., Grishina, O. A. and Sakharov, D. M. (2019). Shadow banking: reasons of emergence and directions of development. International Journal of Civil Engineering and Technology, 10 (2), 1747-1754.

Vishnevskii, V. P., Goncharenko, L. I. and Gurnak, A. V. (2016). Evolution of tax institutions and problems of transition to economic growth. Terra Economicus, 14 (4), 14-30.

Yartseva, N. M. (2015). Tax aspects of economic reform in China. Russian Foreign Economic Herald, 7 , 91-96.

Yuchen, S. and Chengrui, X. (2019). Corporate tax policy and heterogeneous firm innovation: evidence from a developing country. Journal of Comparative Economics, 47 (2), 470-486.

$\begin{array}{llllll}\text { World } & \text { Bank. } & \text { (n.d.). } & \text { GDP } & \text { (current } & \text { US\$). }\end{array}$ https://data.worldbank.org/indicator/NY.GDP.MKTP.CD 